\title{
JIGSAW IV COOPERATIVE LEARNING STRATEGY: CLOSING THE GENDER AND SCHOOL TYPE GAPS IN PHYSICS ACHIEVEMENT OF SENIOR SECONDARY TWO STUDENTS
}

\author{
Macmillan Mafulul Josiah (Ph.D) ${ }^{1}$ and Professor Mangut Mankilik ${ }^{2}$ \\ ${ }^{1}$ Department of Science and Technology Education, Faculty of Education, University \\ of Jos, Jos, Nigeria. Email: mac1jo@yahoo.co.uk \\ ${ }^{2}$ Department of Science and Technology Education, Faculty of Education, University \\ of Jos, Jos, Nigeria
}

Cite this article:

Josiah M.M. and Mankilik M. (2021), Jigsaw IV Cooperative Learning Strategy: Closing the Gender and School Type Gaps in Physics Achievement of Senior Secondary two Students. British Journal of Education, Learning and Development Psychology 4(2), 18-30. DOI: 10.52589/BJELDP2XEDX6PK.

\section{Manuscript History}

Received: 20 Sept 2021

Accepted: 6 Oct 2021

Published: 19 Oct 2021

Copyright $(9) 2020$ The Author(s). This is an Open Access article distributed under the terms of Creative Commons AttributionNonCommercial-NoDerivatives 4.0 International (CC BY-NC-ND 4.0 ), which permits anyone to share, use, reproduce and redistribute in any medium, provided the original author and source are credited.

\begin{abstract}
The study investigated the effects of jigsaw iv cooperative learning strategy (J4CLS) on secondary school students' achievement in Physics in Jos metropolis, Nigeria. It employed the quasi-experimental research design of the nonequivalent control group pre-test, post-test type. One hundred and forty-five (145) senior secondary two (SS II) students from four co-educational secondary schools were used as samples for the study. A 50-item multiple-choice instrument called Heat Energy Achievement Test (HEAT) was used to test students on the concepts of heat energy measurements. The internal consistency of HEAT was estimated at 0.83, using Kuder-Richardson formula 20 on the SPSS Version 25. Three research questions were raised and answered using mean, while two hypotheses were formulated and tested at $\alpha=0.05$ using Analysis of Covariance (ANCOVA). Findings revealed, amongst others, that students taught heat energy measurements using J4CLS achieve significantly higher than students taught under conventional lecture method (CLM); those who were taught heat energy measurements using J4CLS achieved high, without gender and school type bias. Based on the findings, recommendations were made which included encouraging physics teachers to employ J4CLS in teaching secondary school students, since the method has been found to enhance students' achievement in heat energy measurements and it is gender-friendly and independent of school type in terms of improving their achievement in the subject.
\end{abstract}

KEYWORDS: Jigsaw IV Cooperative Learning Strategy, Students' Achievement, Heat Energy Measurements, Physics, Students' Gender, School Type, Nigeria 


\section{INTRODUCTION}

The Nigerian education system recognizes four stages of formal education, namely: preprimary (early childhood) education, which is three years; primary education, which is six years; secondary education, which is also six years and tertiary education, which ranges between three years in Colleges of Education and six years in Universities. Secondary education is further sub-divided into three years each of Junior Secondary School (JSS) and Senior Secondary School (SSS). The six years of primary school education and the three years of JSS education are classified as basic education.

The Federal Republic of Nigeria [FRN], (2014) outlined the core science subjects in the SSS curriculum as Biology, Chemistry and Physics and Abbott (1989) categorized them into biological sciences and physical sciences. Biology falls into the biological sciences and deals with animate matter, while physics and chemistry are physical sciences that deal with the properties and behaviour of inanimate matter. It is somewhat difficult to vividly differentiate between Physics and Chemistry. However, a broad perspective of the difference between the two subjects is that physics deals mainly with the inanimate matter in relation to energy, while chemistry concerns itself with the action of one kind of inanimate matter (substance) on another. The knowledge of these core science subjects, therefore, provides the foundation to science students at the SSS level for further studies in science and science-related courses at the tertiary level.

One of the major national goals of Nigeria is to build a great and dynamic economy. FRN (2014) asserts that the government of Nigeria aims at achieving the goals partly by saddling secondary schools with the responsibility of impacting on students the necessary knowledge and skills; these will subsequently enhance the national economy and arouse the students with the much-desired self-improvement and excellent achievement. In the light of the aforementioned, the Nigerian Educational Research and Development Council [NERDC], (2008) opined that physics is a subject that is critical for effective living in the contemporary science and technology world. This is an indication that the study of Physics at the secondary school level, which is where the basics of physics are taught, should not be underestimated.

Physics is useful to man in all facets of life through its principles, laws and theories. For instance, it is in the electric light that is switched on, the car that is driven, the wristwatch that is strapped on, the cell phone, radio and television set. It is in the equipment used for diagnosing diseases in patients, be it out-patients or in-patients. It is also in the football that is being played or watched. It then means that a decline in the comprehension of physics concepts which underpins the understanding of other fields will result in a gradual decline in the understanding of such fields as agriculture, engineering, medicine and telecommunication. To enhance the study of physics in schools, the contemporary world is shifting focus from teacher-centred instructional strategies to student-centred strategies. This is because teacher-centred methods of teaching do not seem to promote critical thinking skills in students and consequently problem-solving skills, which in turn, lead to improved achievement.

Many student-centred methods of teaching abound, such as cooperative learning, collaborative learning, discovery/inquiry-based learning, problem-based learning, concept mapping, mind mapping, cognitive analysis, games and simulation which are all considered as active learning methods. Student-centred methods of teaching have numerous advantages for the student in the teaching-learning process. One advantage is that such methods of teaching can, according 
to Karamustafaoglu (2009), Tran and Lewis (2012), develop students' learning skills, communication and improve their performance. This implies that student-centred strategies offer students opportunities for practical learning, communicating effectively and being proficient in understanding concepts. Cooperative learning is one of such active learning methods that have this advantage because it is a student-centred method of teaching.

Despite the importance of physics to national development, the situation of students' achievement in physics examinations in Nigeria such as the Senior School Certificate Examination (SSCE) organized by the West African Examinations Council (WAEC) and National Examinations Council (NECO) has been unsatisfactory. Chief examiners' reports indicate that in such examinations, students could not provide correct explanations of evaporation, working principle of a refrigerator, and conversion of heat energy to mechanical energy. They could hardly state correctly four factors that affect the rate of evaporation and could hardly understand basic concepts such as the boiling point of liquids and principles of physics in heat energy. Furthermore, the chief examiners pointed out that many students could hardly go beyond the reproduction of the basic formula for linear expansivity, and were unable to interpret statements into workable diagrams; students exhibited poor manipulation of arithmetic processes and were unable to relate the principle of latent heat of vaporization to the preservation of tomatoes in most jute bags. Furthermore, the reports showed that students defined specific heat capacity instead when they were asked to define heat capacity (NECO, 2009-2012; WAEC, 2015, 2017).

The aforementioned may be a contributory factor to the persistent fluctuations and not too impressive achievement outcomes in the physics examinations. This persistent fluctuation and not too impressive outcome have also been attributed to ineffective methods of teaching physics, such as the conventional lecture method, employed by teachers in the classroom, among others (NECO, 2011, 2012; WAEC, 2015). Boyo's (2010) study on identifying problems associated with studying physics revealed that the conventional lecture method of teaching is ineffective and is still being employed in the physics classroom in Nigeria. This method of teaching physics, which is not student-centred, contradicts the use of contemporary, student-centred methods of teaching physics advocated for by NERDC (2008).

The consequences of allowing the afore-mentioned problems to persist cannot be underestimated. This is because the gradual and subsequent decline in the understanding of physics will affect other physics-related fields such as medicine, agriculture and engineering which will lead to a decline in the health and socio-economy of the nation. This implies that technological advances that drive the economic engines of the nation will gradually collapse. Consequently, the quality of life of the people will deteriorate. The problem, therefore, will be to find if the use of J4CLS will improve secondary school students' achievement in the field of physics in Jos metropolis.

The following research questions were raised for the study:

1. What are the pre-test and post-test mean physics achievement scores of SS II students exposed to J4CLS and the conventional lecture method (CLM)?

2. What are the pre-test and post-test mean Physics achievement scores of male and female SS II students exposed to J4CLS? 
British Journal of Education, Learning and Development Psychology

ISSN: 2682-6704

Volume 4, Issue 2, 2021 (pp. 18-30)

www.abjournals.org

3. To what extent does school type influence the achievement of SS II students in Physics exposed to J4CLS?

One null hypothesis was formulated and tested at a 0.05 level of significance: There is no significant interaction effect of treatment, gender and school type on SS II students' achievement in Physics.

\section{LITERATURE/THEORETICAL UNDERPINNING}

The cooperative learning method is also called small-group learning. It is an instructional method in which small groups of students work on a common task together for the purpose of achieving behavioural objectives of the task. This task can be as simple as members of the small group solving a multi-step physics problem together, or as complex as developing a radioactive centre for a school. There are many cooperative learning strategies such as thinkpair-share, round-robin brainstorming and jigsaw cooperative learning strategy (JCLS). Modifications of the JCLS exist which, according to Timayi, Bolaji and Kajuru (2015), include jigsaw IV cooperative learning strategy (J4CLS). This study focused on J4CLS. The J4CLS allows for teacher introduction of materials, expert group quizzes, review process prior to individual assessment, and re-teaching of only material that was not adequately explored in the cooperative group work (Holliday, 2002; Smith, 2001; Timayi et al., 2015). Illustrations of the J4CLS groups are shown in Figures 1 and 2.

Step 1: Students meet in home groups

\begin{tabular}{|l|l|l|l|l|l|l|l|}
\hline John & Ali & Sule & Lerit & Zira & Joyce & Larai & Audu \\
\hline Ulo & Vou & Dung & Joy & Abang & Musa & Alex & Bala \\
\hline
\end{tabular}

Step 2: Students meet in expert groups

\begin{tabular}{|l|l|l|l|l|l|l|l|}
\hline John & Sule & Ali & Lerit & Ulo & Dung & Vou & Joy \\
\hline Zira & Larai & Joyce & Audu & Abang & Alex & Musa & Bala \\
\hline
\end{tabular}

Step 3: Students return to home groups to teach one another

\begin{tabular}{|l|l|l|l|l|l|l|l|l|}
\hline John & Ali & Sule & Lerit & Zira & Joyce & Larai & Audu \\
\hline Ulo & Vou & Dung & Joy & Abang & Musa & Alex & Bala \\
\hline
\end{tabular}

Fig. 1: Four-student Jigsaw IV Cooperative Learning Strategy using Names 


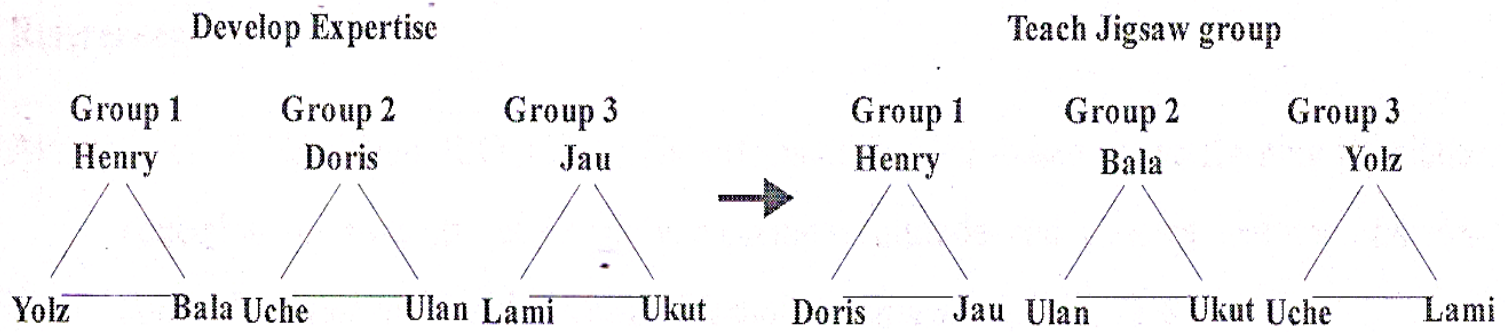

\section{Fig 2: Three-student Jigsaw IV Cooperative Learning Strategy using Names}

The first step of homegroup formation is latent in the illustration of J4CLS in Figure 2. The J4CLS utilizes Jigsaw activities and aims at reducing learning conflict and enhancing positive educational outcomes. It is a grouping method of teaching in which students in a class are organized into 'jigsaw' groups, also called 'home' groups. The students in the jigsaw groups are then re-organized into 'expert' groups containing one student from each jigsaw group. After learning the task assigned, each student goes back to his/her jigsaw group to contribute. This method of teaching can be used to teach students in both theory and practical aspects of physics. However, Maftei and Popescu (2012) were of the view that the jigsaw cooperative learning strategy can yield better results in the practical aspects of physics when students are taught using it.

The groupings in the cooperative learning method include teacher-assigned grouping, randomly-assigned grouping, social integration grouping, subject-matter related grouping, geographic grouping and self-selected grouping. In this study, J4CLS used the teacher-assigned grouping, where the researchers divided the students into small heterogeneous groups of three or four called jigsaw groups. For the purpose of learning, the students in each jigsaw group were then reorganized into expert groups containing one student of the same task from each jigsaw group. The advantage of this way of forming groups is that the teacher can ensure that groups are heterogeneous in terms of academic ability, ethnic background, gender and any other factor that may be relevant. While grouping the students, the teacher ensures that best friends and worst enemies are not placed in the same group. If they are, communication patterns in the group will not be as effective.

This work was anchored on the Constructivism Theory of Learning (CTL), which was propounded by Piaget in 1972. The choice of this theory was because any meaningful learning should involve the content (concepts) and effective method of teaching which should place the learner as an active and constructive participant; and, social relationship of the learner with classmates. Constructivism Theory of Learning views learning as an active, conceptualized process of constructing knowledge by the learner, instead of acquiring it. The constructed knowledge is based on the learner's personal experiences and hypotheses of the environment. Learners continuously test these hypotheses through social negotiation, with each learner having a different interpretation and construction of the knowledge process. This means that each learner contributes his/her past experiences and hypotheses to a given task, instead of being tabula rasa (a blank slate). 
Jigsaw iv cooperative learning strategy (J4CLS) is a suitable method of teaching associated with constructivism. This is because students in J4CLS interact with one another, thereby constructing their own knowledge through sharing their personal experiences on a given Physics task. The students also individually contribute to constructing knowledge through hypothesizing any Physics task (concept) to be accomplished. They also evaluate the workability of the strategy; when they can evaluate they strive towards getting the correct answers to given tasks. Moreover, the strategy increases students' achievement, when used to learn concepts.

Despite the global shift from teacher-centred to student-centred methods, the conventional lecture method of teaching is still the most frequently employed method of teaching physics in Nigerian secondary schools and has been identified by Boyo (2010), Thomas and Israel (2013) to be ineffective and the least performing method. The conventional lecture method of teaching was defined by Ojediran, Oludipe and Ehindero (2014) as a one-way traffic process of teaching and learning with the teacher being active and the students being passive, mere listeners and note-writers. This method of teaching merely involves very little inductive thinking, the reasoning being almost completely deductive. This is because the students are simply passive listeners during the transfer of information by the teacher. Results of students in Senior School Certificate Examinations (SSCE) in physics, organized by West African Examinations Council (WAEC) and National Examinations Council (NECO), have indicated that the conventional lecture method used by teachers in teaching Physics may be ineffective (Josiah, 2020).

Achievement in physics is very important since science and technology can be identified as the effective agent that drives a nation into lofty socio-economic development. Therefore, the continuous poor achievement in physics, or fluctuation in achievement, could spell doom for a nation. These results imply that J4CLS influenced students' achievement in physics to a large extent.

\section{RESULTS/FINDINGS}

\section{Research Question One}

What are the pre-test and post-test mean physics achievement scores of SS II students exposed to J4CLS and the conventional lecture method (CLM)?

The summary of the pre-test and post-test mean Physics achievement scores of SS II students exposed to the J4CLS and the CLM is presented in Table 1. It presents the summary of the data analysis on research question one.

Table 1: Pre-test and Post-test Mean Physics Achievement Scores of SS II Students in Physics Exposed to J4CLS and CLM

\begin{tabular}{lccccc}
\hline Group & \multicolumn{2}{c}{ Pre-test } & \multicolumn{2}{c}{ Post-test } \\
& $\mathrm{N}$ & $\overline{\mathrm{X}}$ & $\mathrm{SD}$ & $\overline{\mathrm{X}}$ & $\mathrm{SD}$ \\
\hline Experimental & 82 & 35.98 & 7.35 & 68.05 & 6.06 \\
Control & 63 & 36.34 & 8.30 & 37.91 & 10.61 \\
\hline
\end{tabular}


The findings in Table 1 reveal respective pre-test and post-test mean Physics achievement scores of 35.98 and 68.05 for students exposed to treatment using J4CLS; while those taught using CLM had respective pre-test and post-test mean Physics achievement scores of 36.34 and 37.91. This finding reveals that not much difference was observed in the pre-test mean Physics achievement scores of students in the two groups. The result, however, further indicates that students exposed to J4CLS had a higher post-test mean Physics achievement score (68.05) than those in the control group (37.91) who were taught Physics using the CLM. This implies that students in the experimental group who were exposed to J4CLS passed the achievement test, while students in the control group who were exposed to CLM failed the test.

\section{Research Question Two}

What are the pre-test and post-test mean Physics achievement scores of male and female SS II students exposed to J4CLS?

Table 2 provides the summary of the pre-test and post-test mean Physics achievement scores of male and female SS II students exposed to J4CLS. It is the summary of the data analysis performed on research question two.

Table 2: Pre-test and Post-test Mean Physics Achievement Scores of SS II Students Exposed to J4CLS

\begin{tabular}{|c|c|c|c|c|c|c|}
\hline \multirow[t]{2}{*}{ Group } & \multirow[t]{2}{*}{ Gender } & \multirow[b]{2}{*}{$\mathrm{N}$} & \multicolumn{2}{|c|}{ Pre-test } & \multicolumn{2}{|c|}{ Post-test } \\
\hline & & & $\bar{X}$ & SD & $\bar{X}$ & SD \\
\hline \multirow{2}{*}{ Experimental } & Male & 44 & 34.73 & 8.02 & 67.45 & 11.69 \\
\hline & Female & 38 & 34.95 & 8.25 & 68.07 & 10.67 \\
\hline
\end{tabular}

The findings in Table 2 reveal that male students exposed to treatment of teaching using J4CLS had respective pre-test and post-test mean Physics achievement scores of 34.73 and 67.45, while their female counterparts had respective pre-test and post-test mean Physics achievement scores of 34.95 and 68.07. This result also shows that not much difference was observed in the mean Physics achievement scores of male and female students after the treatment. This implies that for better achievement in Physics, students should be taught the subject using J4CLS. The findings further show that, though not much difference was observed in the mean Physics achievement scores of male and female SS II Physics students after treatment, female students achieved averagely higher than their male counterparts.

\section{Research Question Three}

To what extent does school type influence the achievement of SS II students in Physics exposed to J4CLS?

Table 3 shows the summary of the pre-test and post-test mean Physics achievement scores of SS II students in public and private schools exposed to J4CLS. It provides the summary of the data analysis on research question three. 
Table 3: Pre-test and Post-test Mean Physics Achievement Scores of SS II Students in Public and Private Schools Exposed to J4CLS

\begin{tabular}{lccccc}
\hline School Type & \multicolumn{2}{c}{ Pre-test } & \multicolumn{2}{c}{ Post-test } \\
& $\mathrm{N}$ & $\overline{\mathrm{X}}$ & $\mathrm{SD}$ & $\overline{\mathrm{X}}$ & $\mathrm{SD}$ \\
\hline Private & 42 & 37.29 & 7.15 & 64.36 & 9.86 \\
Public & 40 & 34.35 & 7.37 & 57.93 & 10.78 \\
\hline
\end{tabular}

Table 3 reveals that students in private school exposed to J4CLS had a pre-test mean Physics achievement score of 37.29, while their counterparts in public school had a pre-test mean Physics achievement score of 34.35. The respective post-test mean Physics achievement scores of students in private and public schools were 64.36 and 57.93. This implies that students exposed to the treatment of teaching using J4CLS in both private and public schools achieved high. The implication of these results is that J4CLS influenced students' achievement in Physics to a large extent.

\section{Hypothesis}

There is no significant interaction effect of treatment, gender and school type on SS II students' achievement in physics.

Table 4 shows ANCOVA results of the interaction effect of treatment, gender and school type on SS II students' achievement in physics. It provides the results of the data analysis on the formulated null hypothesis.

Table 4: ANCOVA Results of Interaction Effect of Treatment, Gender and School Type on Students' Achievement in Physics

\begin{tabular}{llcccc}
\hline & Type III Sum of & \multicolumn{3}{c}{ Mean } & \\
Sources of Variation & Squares & Df. & Square & F & P \\
\hline Corrected Model & $14607.594^{\mathrm{a}}$ & 3 & 2303.797 & 10.804 & .042 \\
Intercept & 1019.874 & 1 & 1019.874 & 43.793 & .000 \\
Treatment & 4607.159 & 1 & 4607.159 & 30.012 & .028 \\
Gender & 20.871 & 1 & 40.871 & 18.217 & .329 \\
School Type & 25.675 & 1 & 55.675 & 8.212 & .037 \\
Treatment*Gender*School & 538.921 & 3 & 38.921 & 1.536 & .018 \\
Type & & & & & \\
Error & 9575.140 & 142 & 156.970 & & \\
Total & 30395.234 & 145 & & & \\
Corrected Total & 20820.234 & 144 & & & \\
\hline
\end{tabular}

. R Squared $=.844($ Adjusted R Squared $=.806)$

Table 4 reveal that $\mathrm{F}(3,145=10.804, \mathrm{p}=0.042)$, that is $\mathrm{p}<0.05$. Based on this, $\mathrm{H}_{\mathrm{o}}$ was rejected and the conclusion is drawn that there was a significant interaction effect of treatment, gender and school type on SS II students' achievement in physics after exposure to J4CLS. The pvalue of 0.018 for the interaction effect of these three variables on students' achievement attested to this fact. The findings further reveal that since $p<0.05$ for treatment and school type, a significant interaction effect of treatment and school type on students' achievement in physics after exposure to J4CLS existed. However, p>0.05 for gender implies that there was no significant interaction effect of gender on students' achievement in physics after exposure to 
J4CLS. The result shows an adjusted R squared value of .806 which means that 80.6 per cent of the variation in the dependent variable, which in this case is SS II students' achievement in physics, was explained by variation in the treatment, gender and school type and that the model was statistically significant at a 0.05 level since its p-value was less than 0.05 . Thereafter, Scheffe's multiple range test was conducted as post-hoc.

The main reason for conducting the post-hoc test in experimental research was to find out where exactly the difference existed between independent variables (treatment and school type) that were found to have significant interaction effect on dependent variable (achievement). Table 5 shows the summary of the Scheffe Multiple range post-hoc test.

Table 5: Summary of Scheffe Multiple Range (Post-Hoc) Test Results for Differences in Interaction Effects of Treatment and School Type

\begin{tabular}{lccc}
\hline Variables & N & Subset for alpha $=0.05$ \\
& & 1 & 2 \\
\hline Public School & 82 & 37.81 & \\
Private School & 63 & 38.89 & 50.41 \\
Experimental Group & 82 & & 1 \\
Sig. & & .959 & \\
\hline p $>0.05$ & &
\end{tabular}

The results for Scheffe's post-hoc test in Table 5 shows that pairing from the multiple comparison results did not reveal a significant interaction effect between students in public and private schools (school type). However, there was a significant interaction effect or difference between the mean achievement scores of SS II physics students in the experimental group (in the two school types) and those in public and private schools since $p>0.05$. This implies that J4CLS, which was administered on the experimental groups in private and public schools, was the source of difference in interaction effect on SS II physics students, and not school type.

\section{DISCUSSION}

The results from research question one as presented in Table 1 revealed the respective pre-test and post-test mean achievement scores of 35.98 and 68.05 for students exposed to treatment using J4CLS; while the respective pre-test and post-test mean achievement scores of students taught with conventional lecture method were 36.34 and 37.91. This finding revealed that not much difference was observed in the achievement mean scores of students in the two groups before the commencement of treatment. The result, however, further indicates that students in the experimental group who were exposed to J4CLS had a higher achievement mean score (68.05) after the treatment than those in the control group (37.91) who were taught physics using the CLM. This implies that students who were exposed to J4CLS passed the achievement test, while students who were taught with CLM still failed the test. This finding conforms to those of Bilesanmi-Awoderu, Oludipe (2012), Sheikhi, Zainalipoor and Jamri (2012) that students who were taught using jigsaw cooperative learning strategy achieved higher than their counterparts who were not exposed to the strategy. 
Table 2 presented the result of research question two. Findings revealed that male students in the experimental group had a mean achievement score of 34.73 before exposure to the treatment of teaching using J4CLS and 67.45 after exposure to the treatment, while their female counterparts had respective mean achievement scores of 34.95 and 68.07 before and after exposure to J4CLS. This result implies that both the male and female students exposed to J4CLS achieved high and that there was not much difference in their mean achievement scores. This finding is in agreement with that of Sheikhi, Zainalipoor and Jamri (2012) that the increase in scores gained by both male and female students exposed to treatment was high. This implies that for better achievement in physics, students could be taught the subject using J4CLS.

The results from research question three, presented in Table 3, revealed that students from private schools who were exposed to J4CLS had a pre-test mean achievement score of 37.29, while their counterparts from public school had a pre-test mean achievement score of 34.35. Furthermore, the post-test mean achievement score of students from private school was 64.36, while that of their counterparts from public school was 57.93. The results further showed that the students from both private and public schools who were exposed to the treatment of teaching using J4CLS to learn physics achieved high. This finding conforms to those of Yusuf, Adigun (2010), Alimi, Ehinola and Alabi (2012) that students from both public and private schools achieved high, with few disparities in their achievements. It is also in line with those of Ayodele (2009), Yusuf, Adigun (2010) and Josiah (2019) that school type has no significant effect on students' achievement. The implication of the present finding is that J4CLS seems to have a great positive effect on secondary school students' achievement in physics, irrespective of school type.

The null hypothesis was formulated to find out if J4CLS, gender and school type have significant interaction effects on students' achievement in physics. The results, presented in Table 4 , revealed that $F(3,145=10.804, p=0.042)$, that is $p<0.05$. Based on this, $H_{o}$ was rejected and the conclusion was drawn that there was a significant interaction effect of treatment, gender and school type on SS II students' achievement in physics after exposure to J4CLS. The p-value of 0.018 for the interaction effect of these three variables on students' achievement attested to this fact. The findings further revealed that since $p<0.05$ for treatment and school type, there existed a significant interaction effect of treatment and school type on students' achievement in physics after exposure to J4CLS. However, $\mathrm{p}>0.05$ for gender implies that there was no significant interaction effect of gender on students' achievement in physics after exposure to J4CLS. The result showed an adjusted $\mathrm{R}$ squared value of .806 which means that 80.6 percent of the variation in the dependent variable, which in this case was the SS II students' achievement in Physics, was explained by variation in the treatment, gender and school type and that the model was statistically significant at a 0.05 level since its p-value was less than 0.05 .

When Scheffe's multiple range test was conducted as post-hoc, J4CLS, which was administered on the experimental groups in the private and public schools, was found to be the source of difference in interaction effect on SS II Physics students' achievement and not school type. This finding was in consonance with the findings of Ayodele (2009) that school type has no significant effect on students' achievement, and Bilesanmi-Awoderu, Oludipe (2012) and Josiah (2019) that jigsaw cooperative learning strategy has a significant effect on students' achievement. 


\section{Implication to Research and Practice}

Students should be taught physics using J4CLS, for improved achievement. This is because the findings of this study revealed that J4CLS can enhance students' achievement when teachers use it in teaching physics concepts, regardless of students 'gender and the type of school they attend.

\section{CONCLUSION}

After exposure, students who were taught physics using J4CLS had a higher achievement mean score than those taught using CLM. It was also found out that both male and female students' achievement in physics improved when they were taught using J4CLS. Furthermore, the study revealed that the achievement of students that were taught physics in both private and public secondary schools using J4CLS increased.

\section{RECOMMENDATIONS}

Based on the findings of this study, the following recommendations are made:

1. Physics teachers should be encouraged to use the Jigsaw IV cooperative learning strategy (J4CLS) in teaching physics in secondary schools since it has been found to improve their achievement.

2. NERDC and STAN should be encouraged to use J4CLS, as a strategy for teaching physics, in planning and developing secondary school curriculum. They should also be encouraged to incorporate this strategy in the publication of textbooks.

3. Ministries of education should be encouraged to formulate policies to make J4CLS a teaching strategy in secondary schools. This is because J4CLS has been found to improve their achievement in heat energy measurements. It has also been found to enhance their achievement in the concepts without bias to students' gender and school type.

\section{Future Research}

This study investigated the effects of jigsaw iv cooperative learning strategy (J4CLS) on students' achievement in senior secondary school physics in Jos metropolis, Nigeria. The following suggestions are hereby made to guide for further studies:

1. This study can be replicated in other Local Government Areas in Nigeria and beyond.

2. The present study can be conducted by operationally defining school types as singlesex and co-educational secondary schools or boarding and day secondary schools.

3. Other concepts in physics, apart from those used in this study can be used for further studies in J4CLS 


\section{REFERENCES}

Abbott, A. F. (1989). Physics. Oxford: Heinemann Educational Publishers.

Abdu-Raheem, B. O. (2012). The influence of gender on secondary school students' academic performance in South-West, Nigeria. Journal of Science Sciences, 31(1), 9398.

Aina, J. K., \& Akintunde, Z. T. (2013). Analysis of gender performance in Physics in colleges of education, Nigeria. Journal of Education and Practice, 4(6), 1-6.

Alimi, O. S., Ehinola, G.B., \& Alabi, F. O. (2012). School types, facilities and academic performance of students in Senior Secondary Schools in Ondo State, Nigeria. International Education Studies, 5(3), 44-48.

Apata, F. S. (2011). Students' gender and numerical proficiency in secondary school Physics in Kwara state, Nigeria. Journal of Research in Education and Society, 2(1), 195-198.

Ayodele, M. O. (2009). Gender differences in mathematics and integrated science achievement among junior secondary school students. MJLI, 6, 41-53.

Bilesanmi-Awoderu, J. B., \& Oludipe, D. I. (2012). Effectiveness of cooperative strategies on Nigerian junior secondary school student's academic achievement in basic science. British Journal of Education, Society \& Behavioural Science, 2(3), 307-325.

Boyo, A. (2010). Identifying problems associated with studying Physics in Lagos State, Nigeria. Retrieved September 2, 2010, from http://www.wcpsd.org/posters/edu cation/ boyo-adenike-I.pdf.

Federal Republic of Nigeria [FRN] (2014). National policy on education ( $6^{\text {th }}$ edition). Lagos: NERDC Press.

Holliday, D.C. (2002). Jigsaw IV: Using student/teacher concerns to improve Jigsaw III. Retrieved from ehc.ed.gov/?id ED465687.

Josiah, M. M. (2019). Jigsaw cooperative learning in Physics: Its impact on secondary school students' achievement in Bukuru metropolis, Nigeria. Global Journal of Academic Research Forum (GLOJACARF), 7(1), 40-50.

Josiah, M. M. (2020). Effects of jigsaw cooperative learning strategy on students' motivation and achievement in senior secondary school Physics in Jos metropolis, Nigeria. An Unpublished Ph.D Thesis, University of Jos, Nigeria.

Karamustafaoglu, O. (2009). Active learning strategies in Physics. Energy Education Science and Technology Part B: Social and Educational Issues, 1(1), 27 -50.

Lubienski, C. A., \& Lubienski, S. T. (2014). The public school advantage: Why public schools outperform private schools. Chicago, IL: University of Chicago Press.

Maftei, G., \& Popescu, F. F. (2012). Teaching atomic physics in secondary school with the jigsaw technique. Romanian Reports in Physics, 64(4), 1109-1118.

National Examinations Council [NECO] (2009). Chief examiners' report SSCE (internal). Abuja: Wins Image Limited.

National Examinations Council [NECO] (2010). Chief examiners' report SSCE (internal). Abuja: Wins Image Limited.

National Examinations Council [NECO] (2011). Chief examiners' report SSCE (Internal). Abuja: Wins Image Limited.

National Examinations Council [NECO] (2012). Chief examiners' report SSCE (Internal) Abuja: Wins Image Limited.

Nigerian Educational Research and Development Council [NERDC] (2008). Senior secondary school physic curriculum for SS 1-3. Abuja: NERDC. 
Ojediran, I. A., Oludipe, D. I., \& Ehindero, O.J. (2014). Impact of laboratory-based instructional intervention on the learning outcomes of low performing senior secondary students in physics. Creative Education, 5, 197-206.

Okoronka, U. A., \& Wada, B. Z. (2014). Effects of analysis instructional strategy, cognitive style and gender on senior secondary school student achievement in some Physics concepts in Mubi Metropolis, Nigeria. American Journal of Educational Research. 2(9), 788-792. Doi:10.12691/education-2-9-13.

Olatoye, R. A., \& Agbatogun A. A. (2009). Parental involvement as correlates of pupils' achievement in mathematics and science in Ogun state, Nigeria. Educational Research and Review, 14(10), 457-464.

Sengul, S., \& Katranci, Y. (2014). Effects of jigsaw technique on mathematics self-efficacy perceptions of seventh grade primary school students. Procedia-Social and Behavioural Sciences, 116, 333-338.

Sheikhi, F. A., Zainalipoor, H. \& Jamri, M. (2012). An investigation into the effect of cooperative learning with a focus on the Jigsaw technique on the academic achievement of 2nd-grade middle school students. Journal of Life Science and Biomedicine, 2(2), 2124. Retrieved from http://jlsb.science-line.com/.

Thomas, O. O., \& Israel, O. O. (2013). Assessing the relative effectiveness of the teaching methods in the measurement of students' performance in Physics. International Journal of Materials, Methods and Technology, 1(8), 116-125.

Timayi, J. M., Bolaji, C., \& Kajuru, Y. K. (2015). Effects of jigsaw IV cooperative learning strategy (J4CLS) on academic performance of secondary school students in geometry. International Journal of Mathematics Trends and Technology, 28(1), 12-18.

Tran, V. D., \& Lewis, R. (2012). The effects of jigsaw learning on students' attitudes in a Vietnamese high education classroom. International Journal of Higher Education, 1(2), 9-20. doi: 10.5430/ijhe.v1n2p9.

West African Examinations Council [WAEC] (2015). WAEC's e-learning tool kit. Retrieved on $7^{\text {th }}$ December 2016 from www.waeconline.org.ng.

West African Examinations Council [WAEC] (2017). WASSCE for school candidates 2016 chief examiner's report (Physics 3). Presented at the $60^{\text {th }}$ anniversary conference of the science teachers association of Nigeria held at Rivers State University, Port Harcourt from $14^{\text {th }}-19^{\text {th }}$ August.

Yusuf, M. A., \& Adigun, J. T. (2010). The influence of school sex, location and type on students' academic performance. International Journal of Education and Science, 2(2), $31-85$. 